\title{
The End of Lifetime Employment in Japan?: Evidence from National Surveys and Field Research
}

\author{
Takao Kato $^{1}$ \\ Department of Economics, Colgate University, Hamilton, New York 13346; Center on Japanese \\ Economy and Business, Columbia Business School, New York; and TCER \\ E-mail: tkato@mail.colgate.edu
}

Received December 28, 2000

\begin{abstract}
Kato, T.-The End of Lifetime Employment in Japan?: Evidence from National Surveys and Field Research

Using both quantitative data from national surveys and qualitative data from our recent field research, this paper provides evidence on the recent transformation of Japan's celebrated practice of lifetime employment (or implicit long-term employment contracts for the regular workforce). Overall, contrary to the popular rhetoric of the end of lifetime employment, evidence points to the enduring nature of this practice in Japan. Specifically, we find little evidence for any major decline in the job retention rates of Japanese employees from the period prior to the burst of the bubble economy in the late 1980s to the post-bubble period. In general, our field research corroborates the main finding from the job retention rates by describing vividly that large firms in Japan have been trying to accomplish their restructuring and downsizing targets by relying heavily on transfers of their employees to their subsidiaries and related firms and hiring cuts, thus avoiding layoffs. Last, the burden of downsizing appears to fall disproportionately on young workers and middle-age workers with shorter tenure. J. Japan. Int. Econ., December 2001, 15(4), pp.489-514. Department of Economics, Colgate University, Hamilton, New York 13346; Center on Japanese Economy and Business, Columbia Business School, New York; and TCER. ๑ 2001 Elsevier Science (USA)
\end{abstract}

Journal of Economic Literature Classification Numbers: J63, J64, J41, O53.

Key Words: long-term employment; lifetime employment; job stability; Japan.

${ }^{1}$ I am grateful to Japan Statistical Association for providing me with unpublished tables from the Employment Status Survey (1997 and 1987), and to Nori Hashimoto for providing me with the data used in his earlier study with John Raisian along with useful notes. My field research was supported and facilitated by NBER, NIRA, JCER, JIL, Rengo-Soken, JPC-SED, Richard Freeman, Professors Koike and Fujimura of Hosei University, Mr. Nakashima and Mr. Koike of Rengo-Soken, and Mr. Fukutani of JPC-SED. I am particularly thankful to the managers, foremen, and union officials 


\section{INTRODUCTION}

Using both quantitative data from national surveys and qualitative data from our recent field research, this paper provides evidence on the recent transformation of Japan's celebrated practice of lifetime employment (or implicit long-term employment contracts for the regular workforce). ${ }^{2}$ Though traditional Japanese employment practices, such as lifetime employment, are not universal phenomena among Japanese firms, they apply to the core of the Japanese labor force, or blue-collar male employees in large firms and white-collar male workers (see, for instance, Koike, 1991). Furthermore, the employment relationship is found to be considerably more of a long-term nature in Japan than in the United States (see, for instance, Hashimoto and Raisian, 1985). ${ }^{3}$

Japanese employers have always felt a need to introduce flexibility into their employment practices. Until recently, however, employers' attempts to weaken traditional employment practices do not appear to have produced any major changes. ${ }^{4}$ Therefore, it is of great topical interest to find out whether Japan's prolonged economic slowdown in the 1990s following the burst of the bubble economy is finally ending these traditional employment practices. While the rhetoric of "the end of lifetime employment" is presently rampant, concrete data on changes in traditional employment practices are relatively scarce (Dore, 1996). We have been collecting and analyzing such data (including both quantitative data from national surveys and qualitative data from our own field research), and this paper presents the first main findings from our analysis of the data.

A closer look at the recent transformation of Japan's lifetime employment system is of particular public policy interest. First, the practice of lifetime employment points to an industrial relations system favorable to successful employee participation which has contributed to the postwar success to Japanese firms, in particular in

of Japanese companies who granted me the opportunities to interview them. An earlier version of the paper was presented at the joint NBER-CEPR-TCER Conference on Unemployment, December 15-16, 2000, Tokyo, Japan and at the Japan Economic Seminar, February 17, 2001, Columbia University. I benefited greatly from comments made by my discussants (Nori Hashimoto, Jenny Corbett, and Hiroyuki Chuma) and other conference and seminar participants as well as an anonymous referee, Jeff Pliskin, and Hugh Patrick. Gabe Schwartz and Justin Nonemaker provided excellent research assistance.

${ }^{2}$ The term "lifetime" is somewhat of a misnomer since, except for executives, Japanese workers have been typically subject to mandatory retirement that occurs between age 55 and age 60 . A precise definition of the practice of lifetime employment is therefore an implicit long-term employment contract that ends at a mandatory retirement age of 55-60 for the regular workforce. In addition, the practice of lifetime employment does not necessarily mean that layoffs never happen in large Japanese firms. It has been documented that Japanese firms, even large ones, did lay off some of their regular employees following the first oil crisis (see, for example, Koike, 1991; Suruga, 1998; Nakata 2000; Chuma, 2001).

${ }^{3}$ According to Higuchi (1997), however, the difference in the importance of long-term employment between Japan and Western European nations appears to be much smaller than between Japan and the United States.

${ }^{4}$ See, for instance, Morishima (1992). 
manufacturing. ${ }^{5}$ Probably as a result of these favorable environments in the postwar Japanese economy, in particular in manufacturing, participatory employment practices were widespread and were established firmly. ${ }^{6}$ Indeed these practices became the hallmark of Japanese management, which has been inspiring (or necessitating in some instances) many corporations in the world to experiment with employee involvement and labor-management cooperation in recent years (see, for instance, Levine, 1995). In short, the practice of lifetime employment can be considered an indispensible ingredient of successful Japanese management.

Second, it has been suggested (see Aoki, 1990, for example) that the Japanese employment system (characterized by lifetime employment, "neuko," enterprise unions, extensive training, and participatory employment practices) is complementary to the Japanese financial system (characterized by stable financial corporate grouping, such as banks and institutional shareholders as stable, long-term suppliers of capital). A closer look at the recent transformation of the Japanese employment system will provide fresh insights on a growing literature on the transformation of the Japanese financial system (see, for example, Hoshi and Kashyap, 1999, and Patrick, 1998).

The economic slowdown in the 1990s (in particular the recent banking crisis) has allegedly been eroding the environments favorable to the practice of lifetime employment. Has the practice of lifetime employment been surviving in Japan since the burst of the bubble economy? If so, how has it been evolving to cope with the new environment that began in the 1990s? Are there any differences between different sectors of the economy in the survival of lifetime employment? Our analysis of quantitative data from national surveys and qualitative data from our own field research on evolving employment practices in the 1990s will shed light on these important questions.

The paper is organized as follows. In the next section, we present quantitative evidence on changes in the prevalence of lifetime employment from the 1980s to the 1990s, using the most recent Employment Status Survey (conducted in 1997 by Japan Statistical Bureau, Ministry of Public Management, Home Affairs, Posts, and Telecommunications) along with the Survey in the previous years. In Section III, we try to corroborate the quantitative evidence from the Employment Status Survey with our field visits which provide detailed and vivid information on the extensive use of reduced hiring and transfers of employees to subsidiaries and related firms as alternatives to layoffs. A concluding section then follows.

\section{CHANGES IN THE JOB RETENTION RATES OF JAPANESE EMPLOYEES}

Following the procedures developed by Hall (1982) and later applied to the Japanese data by Hashimoto and Raisian (1985), we use the Employment Status

${ }^{5}$ For participatory employment practices in Japan, see Jones and Kato (1995), Kato and Morishima (2001), and Kato (2000) for example.

${ }^{6}$ See, for instance, Kato and Morishima (2001). 
Survey and estimate the job retention rates of Japanese employees. Interest in studies of the importance of long-term employment in the United States has been rekindled recently in light of the rising popular perception of disappearing long-term jobs in the United States. In response, a number of researchers in the United States have been using CPS tenure supplements to address this popular perception (see, for example, Neumark and Polsky, 1998, and Farber, 1998). The Employment Status Survey is the Japanese counterpart of the CPS tenure supplements of the United States. ${ }^{7}$ The Survey is conducted every five years, and some cross tabulations from the Survey are published accordingly. ${ }^{8}$ We recently obtained unpublished tables from the 1997 Survey as well as the 1987 Survey and the 1977 Survey which contain sufficient information for calculating the 10 -year job retention rates of Japanese employees for the 10 -year period prior to the burst of the bubble economy (1977-87) and the post-bubble period (1987-97). ${ }^{9}$

As shown in Table I, in 1977, $18.55 \%$ of the civilian noninstitutional population ages 15-19 were employees (as opposed to self-employed and not in the labor force) and had been with the same employer for 4 years or less (or in the $0-4$-year tenure category). Ten years later in $1987,6.1 \%$ of the civilian noninstitutional population ages 25-29 were employees in the 10-14-year tenure category. According to Hall (1982) and Hashimoto and Raisian (1985), the 10-year job retention rate of all employees ages 15-19 with 0-4 years of tenure in 1977 was

${ }^{7}$ There is, however, an alternative dataset available for Japan, i.e., the Wage Census data. Though the Wage Census data are obtained from an establishment-level survey and hence not comparable to CPS tenure supplements, they provide information necessary to calculate job retention rates. For example, Chuma (1998a) analyzed the Wage Census data thoroughly and found no evidence for the weakening lifetime employment in the 1980s and the early 1990s. Using the most recent Employment Status Survey data which extend the time period under scrutiny to the late 1990s, we essentially confirm his earlier finding. In addition, the use of the Employment Status Survey allows for a comparison of the job retention rates between Japan and the United States.

${ }^{8}$ Hashimoto and Rasian (1985) used earlier years of the same survey for Japan and CPS tenure supplements for the United States and compared the importance of long-term employment between the two nations in the 1960s and the 1970s.

${ }^{9}$ We focus on the 10 -year job retention rates rather than the 15 -year job retention rates that Hashimoto and Raisian (1985) calculated since we are interested in the impact of the significant economic slowdown in the 1990s, following the burst of the bubble economy. Our comparison of the 10-year job retention rates between the 10-year period preceding the burst of the bubble economy and the 10-year period immediately following the burst will allow us to detect appropriately any erosion of lifetime employment in the post-bubble trouble of the Japanese economy. On the other hand, unfortunately, given that prior to 1977 the Survey was conducted every three years instead of every five years, it is impossible to calculate the 15 -year job retention rates consecutively from the period prior to the burst of the bubble economy to the post-bubble period. It is, however, possible to calculate the 15-year job retention rates for 1982-1997 and compare them to the 15-year job retention rates for 1962-1977 that Hashimoto and Raisian (1985) calculated. As shown later, this comparison reassuringly confirms our key findings from comparing the 10-year job retention rates between 1977-87 and 1987-97. 


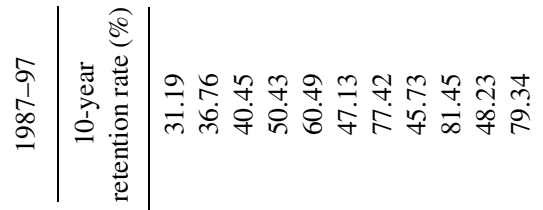

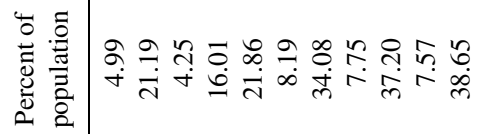

ลิ

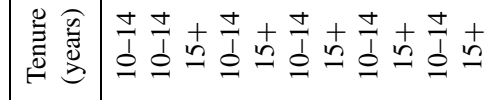

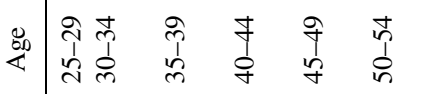

$\frac{\hat{\sigma}}{\tilde{\sigma}}$

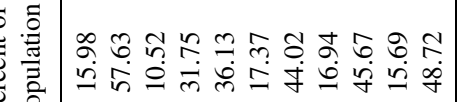

๙ิ

远高

ลू

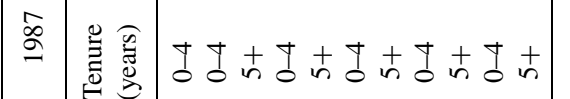

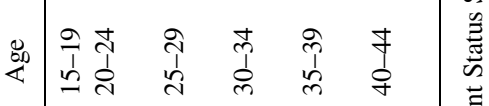

คิ

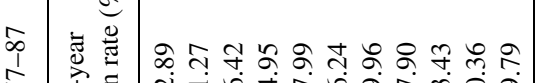

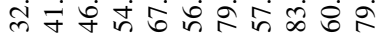

ล

응 올

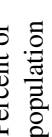

으 ᄁᄁ

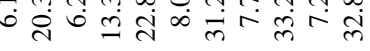

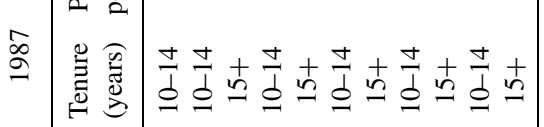

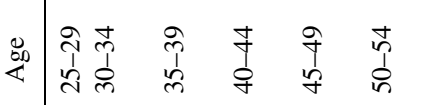

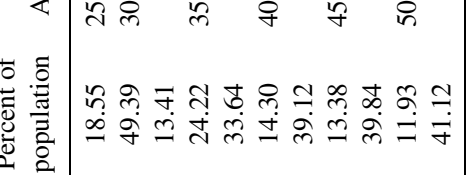

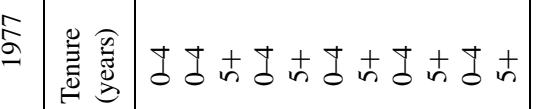

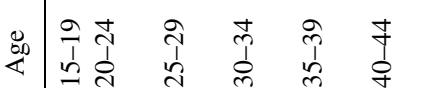


$6.1 / 18.55=32.89 \% .^{10}$ In other words, in 1977 the average employee ages $15-19$ with $0-4$ years of tenure in Japan had a $32.89 \%$ chance of being with the same employer 10 years later. ${ }^{11}$ The table also shows the 10 -year job retention rates of employees in various age-tenure categories in $1977 .{ }^{12}$ We repeated the same calculations for the most recent 10 -year period of 1987-97. The results are also shown in Table I. ${ }^{13}$

Overall, we find little evidence for serious erosion of the practice of lifetime employment. Specifically, among core employees of Japanese firms (or those who are 30-34, 35-39, and 40-44 years old with 5+ years of tenure), the 10-year job retention rate was around $80 \%$ for the bubble period of 1977-87. In other words, four in five core employees of Japanese firms in 1977 retained the same job 10 years later. The situation changed little for the post-bubble period of 1987-97. Approximately four in five core employees of Japanese firms in 1987 survived the turbulent years of the Japanese economy and retained the same job 10 years later.

On the other hand, among younger employees (ages 20-24 and 25-29) and middle age employees with short tenure (ages 30-34, 35-39, and 40-44 with 0-4 years of tenure), the job retention rates fell noticeably from the bubble period to the postbubble period. For example, 58\% of employees ages 35-39 with 0-4 years of tenure in 1977 retained the same job 10 years later whereas only $46 \%$ did in 1987.

${ }^{10}$ We assume (so did prior studies) that no employees separates from his or her firm, works for other firms for a few years, and returns to the initial firm. To the extent to which some employees follow this pattern, the calculated job retention rates overstate the importance of long-term employment. Unfortunately, we have no systematic data to account for this possible bias. However, in the Japanese labor market, we speculate very few employees follow this pattern. Note that some employees on fixedterm transfer (shukko) to subsidiaries and related firms, as we discuss in the next section, will return to the original firm. However, since those on fixed-term transfer keep their employment relationship with the initial firm while on transfer, it appears to be appropriate to count their time on fixed term transfer in their tenure with the original firm. A potentially more important measurement issue with the job retention rates arises from the fact that many of those on fixed transfer are indeed permanently transferred and separated from the original firm eventually. We will discuss this measurement issue in the next section more fully.

${ }^{11}$ Hall (1982) and Hashimoto and Raisian (1985) divide the number of employees in each age-tenure category by the civilian noninstitutional population in the corresponding age category. We follow the same procedure in the paper. However, using the number of employees in each age-tenure category itself instead will change the 10-year job retention rates very little.

12 We eliminated the category of ages 15-19 and tenure 5+ as Hashimoto and Raisian (1985) did since there were very few people in this category. For 1977, the number of employees with less than one year of tenure was available only for the age category 40-54 and was not available for 40-44, 45-49, and 50-54 separately. We used the number of employees with one year of tenure for each of these three age categories in 1977 to estimate the number of employees with less than one year of tenure for each of these three age categories. Since there were relatively few people in those three age-tenure categories, we are confident that using these estimates rather than the actual numbers will have little impact on the 10-year job retention rates of employees ages 40-44, ages 45-49, and ages 50-54 in 1997.

${ }^{13}$ Since mandatory retirement happened typically between ages 55 and 60 during the time period being studied and thus the practice of lifetime employment does not apply to those over age 55, we focus on calculating the 10 -year job retention rates for employees who were younger than 45 at the base year. 
The practice of lifetime employment is often said to apply only to male employees, and female employees sometimes serve as a shock absorber in Japan. ${ }^{14}$ Tables II and III show the 10-year job retention rates of male and female employees for 1977-87 and 1987-97.

As expected, the 10-year job retention rates were considerably lower for female employees than for male employees for all age-tenure categories and for both bubble and post-bubble periods. The difference was particularly large for young employees ages 15-19, 20-24, and 25-29. For instance, the probability for a male employee ages 20-24 to be with the same employer 10 years later was three times higher than for the female counterpart. Interestingly, among middle age female employees with 5+ year of tenure, the 10-year job retention rates were around 70\% and the gender difference was not as pronounced as among younger employees and middle age employees with short tenure.

Regarding changes in the 10-year job retention rates over time, we find more discernible declines in the retention rates among female employees than among male employees. In particular, among female employees ages 30-34, 35-39, and 40-44 with short tenure ( $0-4$ years), the 10-year job retention rates fell substantially from the bubble period to the post-bubble period. For example, female employees ages 35-39 and 0-4 years of tenure enjoyed an almost $60 \%$ chance of 10 -year job retention for 1977-87 whereas they enjoyed only about $40 \%$ of 10 -year job retention for 1987-97.

In sum, evidence points to the enduring nature of the practice of lifetime employment, in particular for prime age male employees. The burden of downsizing during the economic slowdown in the 1990s appears to have fallen disproportionately on young employees and middle age employees with short tenure, in particular middle age female employees with short tenure.

Next, using the 1982 and 1997 Employment Status Survey, we calculated the 15 -year job retention rates of male employees and compared them to the 15-year job retention rates of male employees for 1962-1977 that Hashimoto and Raisian (1985) calculated. As shown in Table IV, lifetime employment is still alive and well for core employees ages 25-39 with 5+ years of tenure who continue to enjoy over a $70 \%$ chance of being with the same employer 15 year later. Furthermore, comparing the 15-year job retention rates of male employees for 1982-97 to the ones for 1962-77 that Hashimoto and Raisian (1985) calculated points to the enduring nature of the practice of lifetime employment. The only age-tenure group who experienced a noticeable fall in the 15 -year job retention rate is young employees ages 20-24 with $5+$ years of tenure who were only $12.2 \%$ of the corresponding population in $1982 .{ }^{15}$

${ }^{14}$ See, for instance, Abraham and Houseman (1989).

15 Another key finding of Hashimoto and Rasian (1985) is that the importance of tenure in earnings profiles of male employees is much greater in Japan than in the United States. There has been a controversy over this finding. Clark and Ogawa (1992) re-estimated earnings equations of Hashimoto and Rasian (1985) using more recent data and suggested a significant change in the Japanese labor 


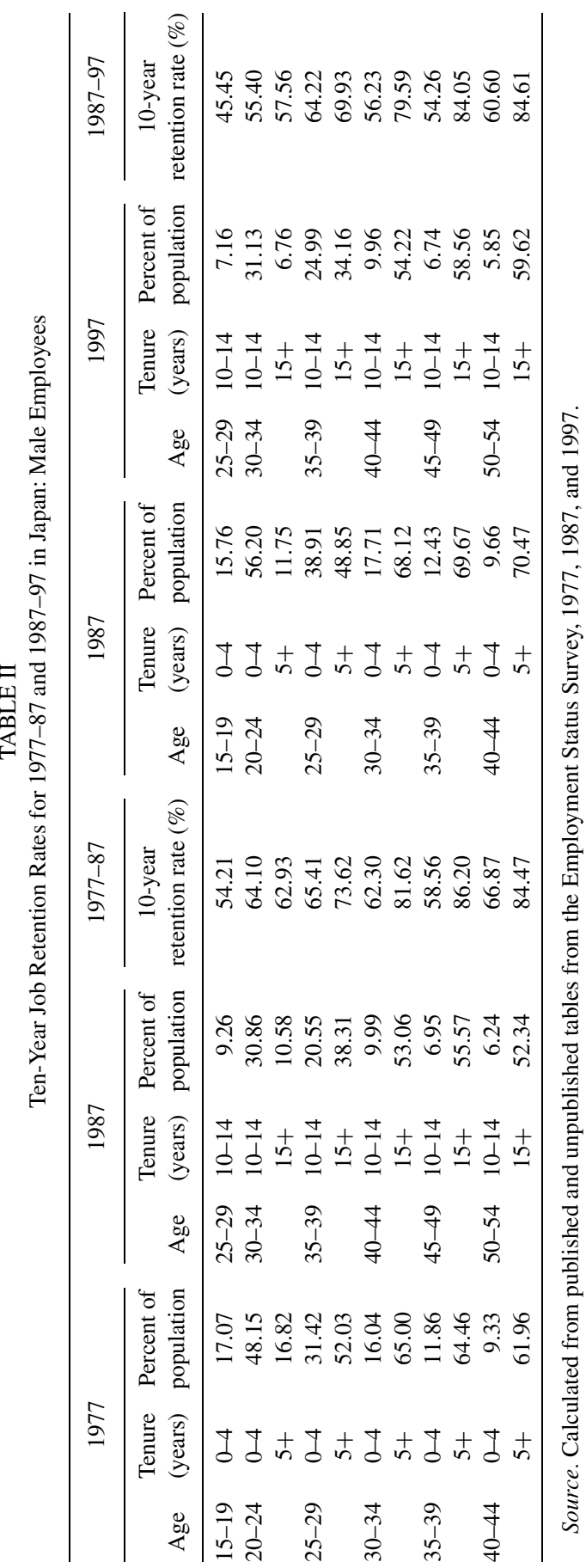




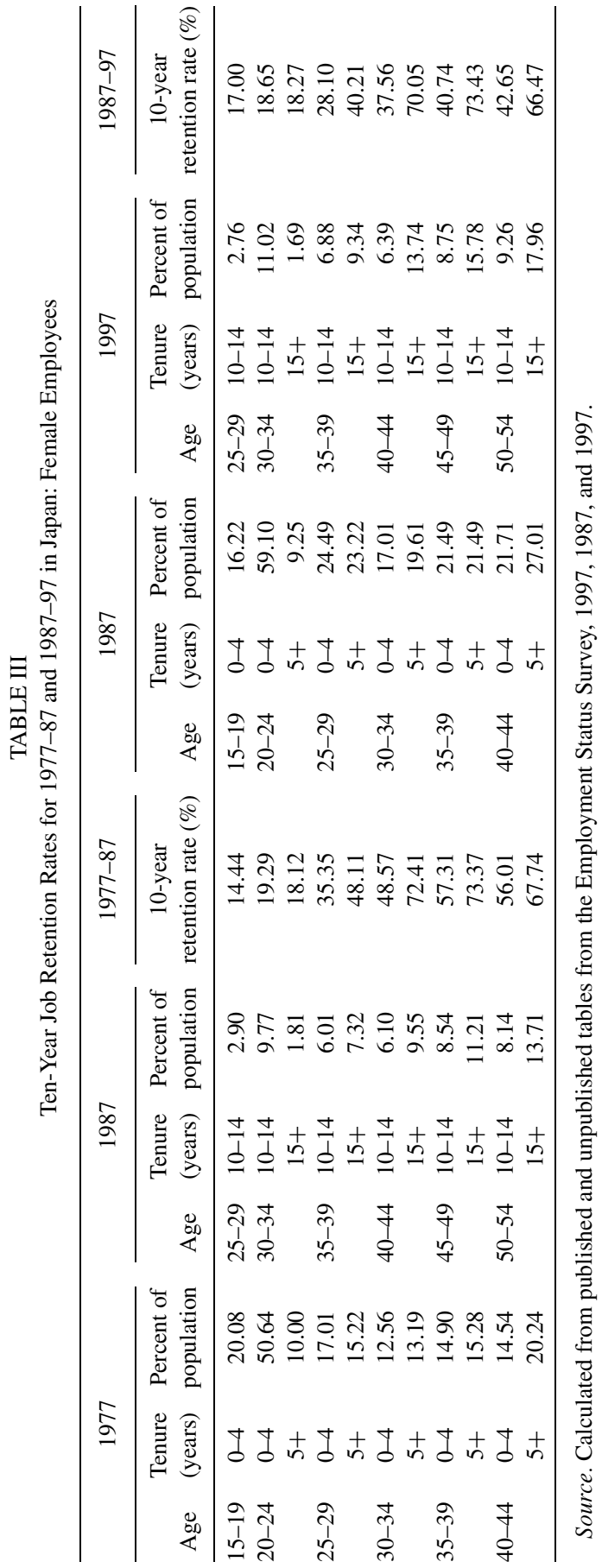


TABLE IV

Fifteen-Year Job Retention Rates for 1982-97: Male Employees

\begin{tabular}{|c|c|c|c|c|c|c|c|}
\hline \multicolumn{3}{|c|}{1982} & \multicolumn{3}{|c|}{1997} & \multirow{2}{*}{ 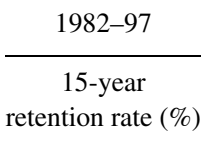 } & \multirow{2}{*}{$\begin{array}{c}1962-77 \\
15 \text {-year } \\
\text { retention rate }(\%)^{a}\end{array}$} \\
\hline Age & $\begin{array}{l}\text { Tenure } \\
\text { (years) }\end{array}$ & $\begin{array}{l}\text { Percent of } \\
\text { population }\end{array}$ & Age & $\begin{array}{l}\text { Tenure } \\
\text { (years) }\end{array}$ & $\begin{array}{l}\text { Percent of } \\
\text { population }\end{array}$ & & \\
\hline $15-19$ & $0-4$ & 16.85 & $30-34$ & $15-19$ & 6.74 & 39.99 & 36.40 \\
\hline \multirow{2}{*}{$20-24$} & $0-4$ & 53.70 & $35-39$ & $15-19$ & 27.43 & 51.08 & 45.10 \\
\hline & $5+$ & 12.20 & & $20+$ & 6.74 & 55.22 & 65.30 \\
\hline \multirow[t]{2}{*}{$25-34$} & $0-4$ & 24.84 & $40-49$ & $10-14$ & 12.98 & 52.24 & 42.70 \\
\hline & $5+$ & 59.35 & & $15+$ & 43.70 & 73.64 & 73.00 \\
\hline \multirow[t]{2}{*}{$35-39$} & $0-4$ & 10.74 & $50-54$ & $15-19$ & 5.01 & 46.65 & 37.70 \\
\hline & $5+$ & 69.62 & & $20+$ & 54.61 & 78.44 & 75.90 \\
\hline
\end{tabular}

Source. Calculated from published and unpublished tables from the Employment Status Survey, 1982 and 1997.

${ }^{a}$ From Table 1 of Hashimoto and Raisian (1985).

Finally, Hashimoto and Raisian (1985) compared the 15-year job retention rates of male employees between Japan and the United States and concluded that in the 1960s and 1970s long-term employment was indeed more prevalent in Japan than in the United States. We undertook a similar cross-national comparison for more recent years. The results are summarized in Table V. Long-term employment continued to be more prevalent in Japan than in the United States for all tenure-age categories throughout the 1980s and 1990s. Comparing our results to the original Hashimoto and Raisian results demonstrates that the differences in the 15-year job retention rates of male employees between the two nations appear to be remarkably stable over the past four decades. For instance, according to Hoshimoto and Raisian (1985), among male employees ages 25-34 with 5+ years of tenure in the early 1960s, 73\% retained the same job 15 years later in Japan whereas only $47 \%$ did so in the United States. We found that among the same category of employees in the early 1980s, 74\% kept the same job 15 years later in Japan whereas only $48 \%$ did so in the United States.

\section{EVIDENCE FROM FIELD RESEARCH}

During the summer of 1999, we conducted field research at a number of Japanese firms. During the winter of 1999, we had written to both managements and unions, asking to locate and assemble some specific data on their employment practices, and detailing what kind of questions we intended to ask when we visited them

market in the 1980s, specifically a substantially diminished role of tenure in earnings profiles of Japanese male employees in the 1980s. In response, Hashimoto and Rasian (1992) discounted the Clark and Ogawa conclusion by providing additional evidence which is more mixed than that provided by Clark and Ogawa (1992). Our finding of stable job retention rates over time appears to be more consistent with the cautionary view of Hashimoto and Rasian (1992) on changes in the Japanese labor market. 
TABLE V

Fifteen-Year Job Retention Rates of Male Employees in the 1980s and 1990s:

Japan and the United States

\begin{tabular}{|c|c|c|c|}
\hline \multicolumn{2}{|c|}{1982 (1983) } & \multirow{2}{*}{$\begin{array}{c}\frac{\text { Japan }(1982-97)}{15-y e a r} \\
\text { retention rate }(\%)\end{array}$} & \multirow{2}{*}{ 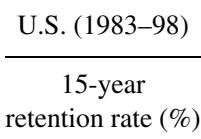 } \\
\hline Age & $\begin{array}{l}\text { Tenure } \\
\text { (years) }\end{array}$ & & \\
\hline $15-19$ & $0-4$ & 39.99 & 4.59 \\
\hline \multirow[t]{2}{*}{$20-24$} & $0-4$ & 51.08 & 13.92 \\
\hline & $5+$ & 55.22 & 28.45 \\
\hline \multirow[t]{2}{*}{$25-34$} & $0-4$ & 52.24 & 20.13 \\
\hline & $5+$ & 73.64 & 48.14 \\
\hline \multirow[t]{2}{*}{$35-39(35-44)^{a}$} & $0-4$ & 46.65 & 22.06 \\
\hline & $5+$ & 78.44 & 52.14 \\
\hline
\end{tabular}

Source. Calculated from published and unpublished tables from the Employment Status Survey, 1982 and 1997 (Japan) and CPS Tenure Supplements, 1983 and 1998 (U.S.).

${ }^{a} 35-39$ for Japan and 35-44 for the U.S.

during the summer of 1999. They took our request seriously and spent much time and effort to prepare often confidential data for us. ${ }^{16}$

In addition to the obvious advantage of field research being detailed and allowing richer analysis, there is also an added advantage. The above analysis of the Employment Status Survey does not tell us anything about changes in the practice of lifetime employment after 1997. It is conceivable that the impact of the economic slowdown may be appearing only after 1997. Our field research from the summer of 1999 provides the most recent picture of employment practices.

We introduce three cases here which demonstrate the scope and nature of Japanese-style downsizing most vividly. All three cases are large manufacturing firms in three representative industries in Japan who downsized their labor force considerably in the 1990s. Each firm is a leading firm in its industry and is a familiar name not only domestically but globally.

\section{a. Firm A}

Firm A is a large manufacturing firm with sales of over 3 trillion yen (nearly half of which is export sales) and employment close to 40,000 workers in 1998. It is publicly traded in the first section of the Tokyo Stock Exchange. The corporation has 11 establishments in addition to its corporate headquarters.

Figures 1 and 2 summarize the changes in key characteristics of Firm A for the past two decades. Figure 1 shows sales in 1982 yen, labor (the total number of employees), and share price (the annual average price of stock). All variables in Fig. 1 are relative to their 1982 levels. Note that those on fixed-term transfer to other firms (shukko) are included in labor. We also calculated standard accounting

${ }^{16}$ We interviewed both managements and unions to maximize the accuracy of the information. Kato (2000) describes this field research in more detail. 


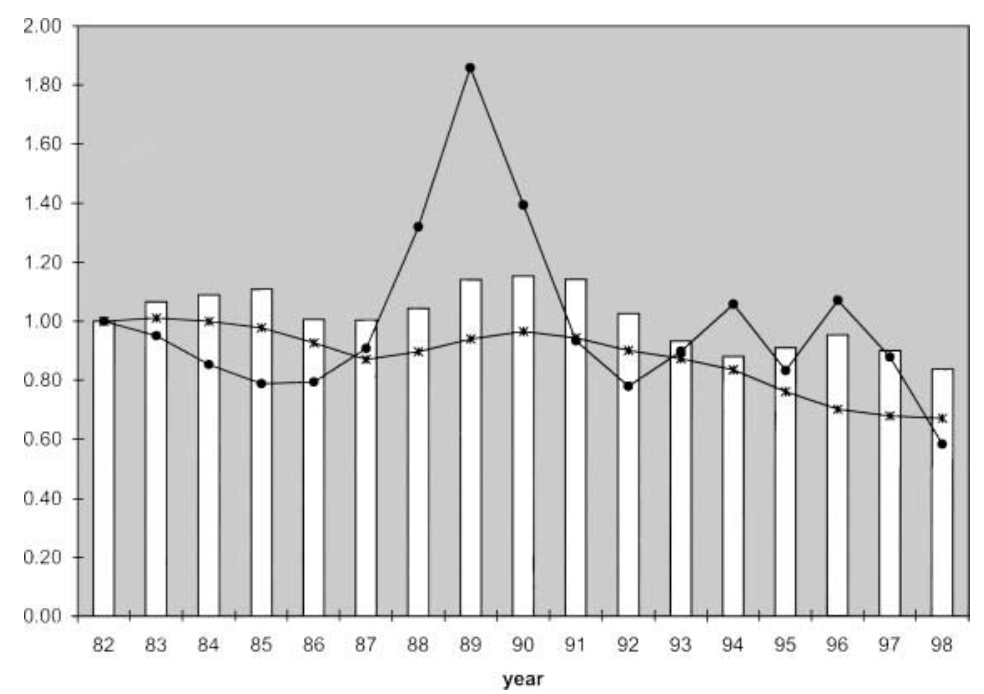

FIG. 1. Changes in key firm characteristics over time: Firm A. $\square$, sales; $*$, labor; $\bullet$, share price.

firm performance measures such as ROA and ROE as well as shareholder returns (a standard economic firm performance measure or rate of change in share price plus dividend rate) and plotted them in Fig. 2. It is obvious from the tables that in the 1990s the firm's performance worsened and became more volatile. It cut

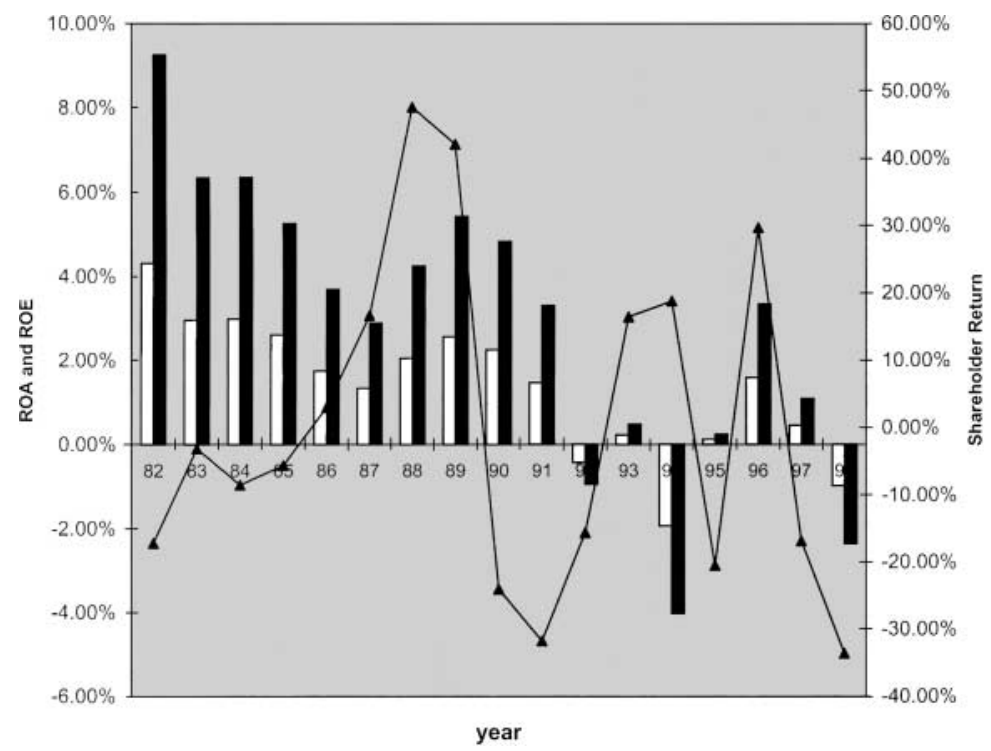

FIG. 2. Changes in firm performance measures over time: Firm A. $\square$, ROA; $\square$, ROE; $\boldsymbol{\Delta}$, Shareholder return. 
$30 \%$ of its labor force throughout the 1990s from about 57,000 employees to about 40,000 employees. This downsizing was primarily accomplished by a combination of limited hiring and transfers of workers to related firms without laying off workers.

The firm hired over 3,000 college and high school graduates right after their graduation in 1990. In the next three years, the firm continued to reduce this new graduate hiring and hired about 2,000 graduates in 1993. New graduate hiring was extremely restrained in the next four years, ranging from 482 to 62 graduates. The new graduate hiring level did bounce back somewhat in 1998 and 1999, reaching 1,000 graduates.

As shown in Table VI, on average over 2,000 employees were transferred to Firm A's sales firms, other related firms, and other unrelated firms each year on a fixed-year term (typically two-year term) for 1995 and $1996 .{ }^{17}$ Those on fixed term transfer continue to be employees of Firm A and thus there is no break in their tenure with Firm A. They continue to be on Firm A's payroll. The number of fixed-term transfers has recently declined to a little over 1,000 employees. The status of some of those on fixed-term transfer was changed to permanently transferred (tenseki), and they were no longer employees of Firm A. Between 600 and 700 workers were permanently transferred each year for the last four years except for the most recent year when the firm experienced a substantial reduction in the number of permanent transfers. Since most of those permanently transferred were on fixed-term transfer initially, these numbers suggest that roughly $30 \%$ of those on fixed-term transfer never returned to the firm and became permanently transferred. Almost all employees on fixed-term transfer were over 50 years old and white-collar workers. The majority of fixed term transfers are to Firm A's sales firms whereas permanent transfers were more evenly distributed between sales firms and other related firms. Note that a nonnegligible number of employees were transferred to nonrelated firms. When a worker is permanently transferred, the firm pays his or her a severance pay of up to five years of his or her annual base wage.

Permanent transfers do present some shopfloor morale problems. An employee complained: "I wished I could have remained in Firm A and have attended my daughter's wedding as a proud employee of Firm A." Being an employee of a famous and prestigious company such as Firm A means status. Although a permanent transfer might make sense financially, many employees accept permanent transfer with some mixed feelings.

In addition, the firm used a special early retirement incentive plan during 1995. The amount of the incentive pay was considerable: at age 30, an early retiree was offered 12 months of monthly pay in addition to his or her standard pension; at age 40, 18 months; at age 50, 48 months; at age 58, 3 months. The incentive pay induced over 4,000 early retirements (retirements before the firm's mandatory retirement age of 60) successfully during the year. Most early retirees were not

${ }^{17}$ For an earlier study of fixed-term transfers, see Brunello (1988). 


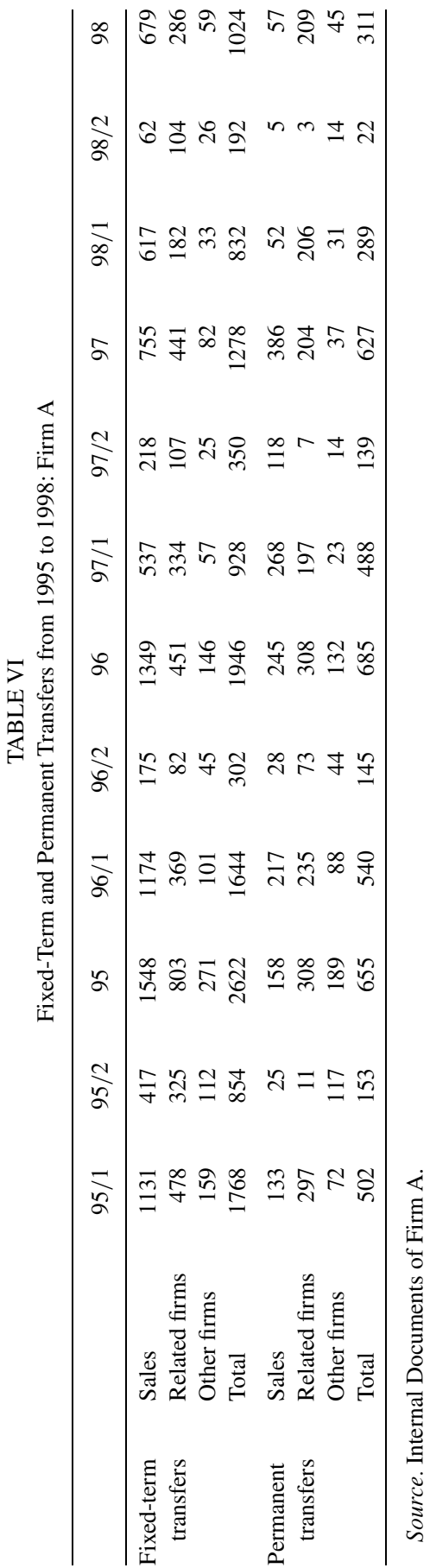




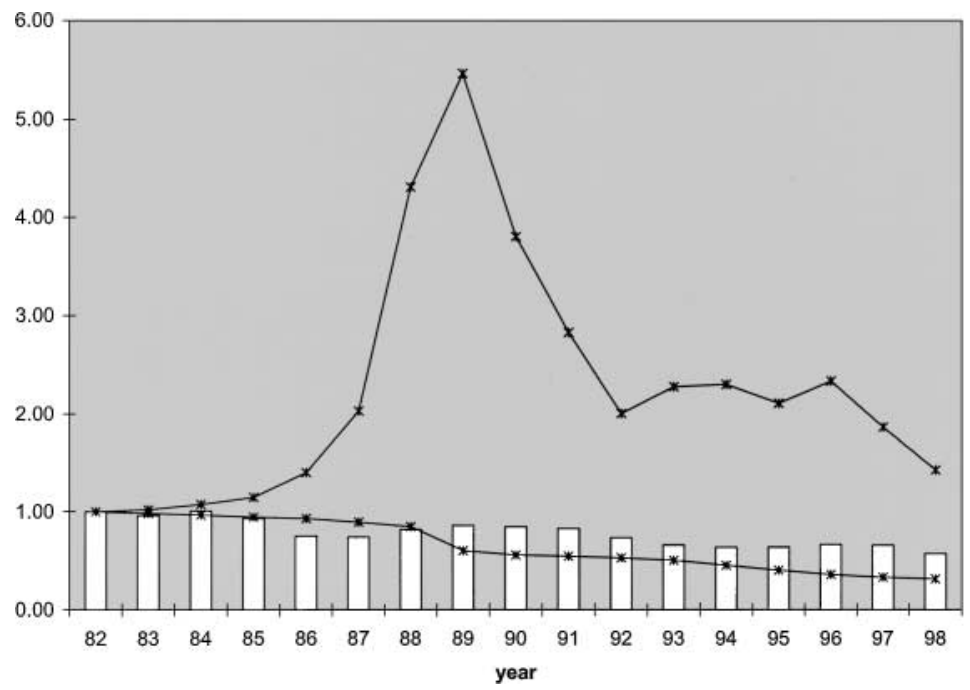

FIG. 3. Changes in key firm characteristics over time: Firm B. $\square$, sales; $*$, labor; $*$, share price.

far from their mandatory retirement age of 60 . The firm was again using a similar early retirement incentive plan at the time of our field visit. ${ }^{18}$

In general Firm A's use of part-time employees was quite modest. In the process of this downsizing, the amount of work did not decline as fast as the number of employees. To cope with this overload of existing full-time regular employees, the firm increased the number of part-time employees. In January 1994, the firm had 64 part-time employees. In January 1999, the firm had 123 part-time employees: 82 (67 female) of them were engaged in clerical and other white-collar work whereas 36 (33 female) of them were engaged in simple manual tasks to assist regular production workers (such as moving materials); and 5 of them actually worked as production workers.

\section{b. Firm B}

Firm B is a large manufacturer with sales of a few trillion yen (about one quarter of which is export sales) and employment close to 20,000 workers in 1998. It is also listed in the first section of the Tokyo Stock Exchange. The firm has over ten establishments.

Figures 3 and 4 summarize changes in key characteristics of Firm B for the past two decades. Firm performance continued to worsen in the 1990s. It cut almost $50 \%$ of its labor force throughout the 1990s. This downsizing was primarily accomplished by a combination of limited hiring and transfers of workers to other firms without laying off workers.

${ }^{18}$ Since many of those taking early retirement options were nearing their mandatory retirement age of 60 and were scheduled to retire in a few years anyway, it is somewhat unclear how effective the early retirement incentive plan was as a means of downsizing. 


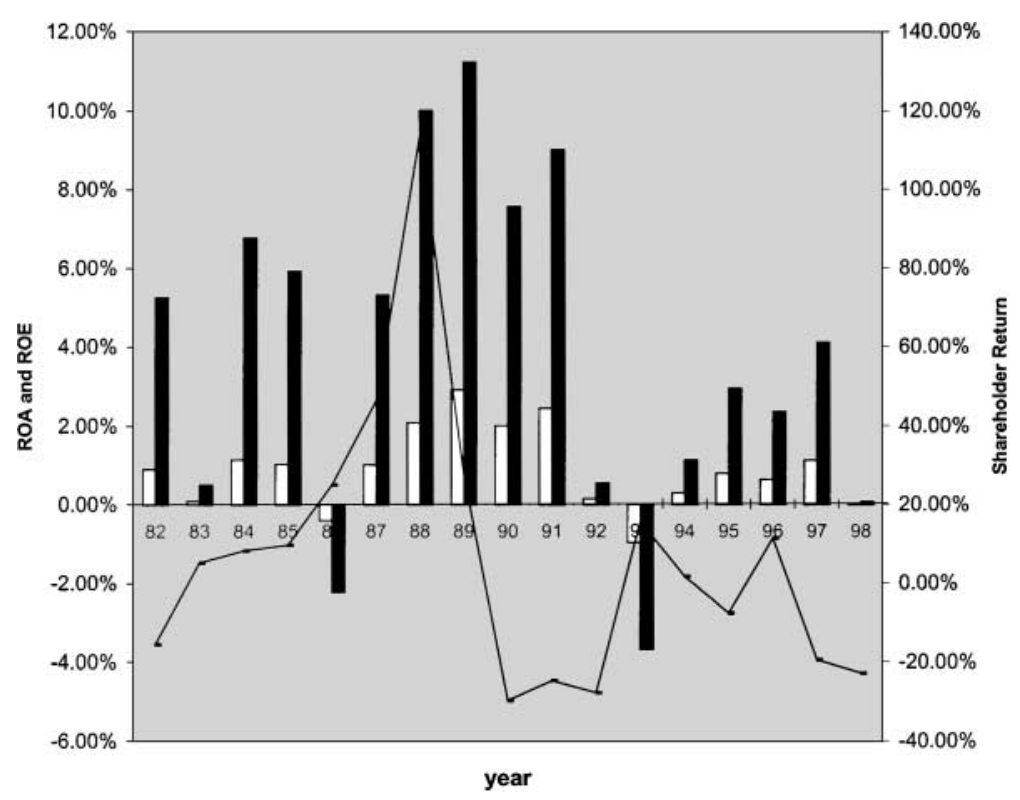

FIG. 4. Changes in firm performance measures over time: Firm B. $\square$, ROA; $\square$, ROE; $\square$, shareholder return.

Firm B hires college and high school graduates right after their graduation as regular employees and rarely hires those with full-time work experience. The only recent exception was during 1990 and 1991 when over 100 experienced workers were brought in from other industries. In 1990 and 1991, the firm was starting a new business and needed a large number of experienced workers quickly. The firm did not engage in any active raiding of these employees from other firms yet it did use a headhunting firm to identify a few key employees and sought them after aggressively.

Until the early 1990s, approximately 1,000 new college and high school graduates were hired upon graduation. Since 1995, however, the firm has cut its hiring by nearly two thirds. The firm's recent reductions in hiring were more acute for white-collar occupations than for blue-collar occupations. For example, in 1991, the firm hired 800 workers into white-collar occupations (most of them were college graduates) white it hired only 150 in 1999.

In parallel to a hiring cut, like Firm A, Firm B used employee transfers as a main device of downsizing. Most important is fixed-term and permanent transfers to other firms. From 1991 to 1993, the firm transferred on average over 1,000 employees (about two thirds of them white-collar) a year to various firms on a three-year term. The number of fixed-term transfers rose dramatically for the following three years, amounting to on average 3,000 employees (half of them white-collar) dispatched to other firms every year. The level of transfer activity has returned to the 1991-93 level; i.e., about 1,000 employees (the majority of 
them white-collar) have been transferred to other firms on a three-year term every year for the last two years (1997 and 1998).

The firm sought possible fixed-term transfer outlets among its related firms first. However, given its magnitude, it was impossible to find all necessary transfer outlets among those related firms, and therefore the firm worked hard to cultivate alternative transfer outlets, including nonmanufacturing firms, such as salespersons for wireless phones, and the public sector, such as schools. Normally, those who are considered for transfer will be consulted by the immediate supervisor in advance. The extent to which this consultation takes place depends on how familiar transfer outlets are to these transfer-bound employees. Some outlets are familiar places for its employees in which many of their former colleagues are working as a result of transfers in the past. Transfers to such familiar places do not require careful consultation. On the other hand, transfers to some unfamiliar firms require thorough consultation. As previously mentioned, the typical term of transfer is three years. However, in reality, many of those on fixed-term transfer became permanently transferred and never returned to the firm. Normally, only those who were transferred on a fixed term to help the firm's subsidiaries and related firms as technical advisors return to the parent firm after the term is over. As such, fixed-term transfers are viewed as a first step for eventual permanent transfers by many employees. Typically, near-retirement employees are approached for possible transfers. Only employees over age 55 are subject to permanent transfers. Both union and management argue that those who are 55 or older and already on fixed-term transfer often prefer to be permanently transferred and continue to work there till the mandatory retirement age of 60 rather than returning to the firm and spending several years at the original firm before retirement.

Over 1,000 employees were permanently transferred on average every year from 1991 to 1993. About 70\% were white-collar employees. The number of permanent transfers increased to nearly 4,000 (about half of them white-collar) per year on average during the next three years. Permanent transfers leveled off somewhat recently, and about 2,500 employees were permanently transferred every year on average during the last two years. When an employees is permanently transferred, Firm B pays him or her a severance pay which compensates for any loss in income as a result of leaving Firm B prior to the mandatory retirement age of 60 .

Firm B used to use transfers of production workers to other plants within the firm (haiten) more heavily in comparison to transfers of such workers to other firms. ${ }^{19}$ However, in the 1990 s, transfers to other plants within the firm became an insignificant practice; i.e., only 200 employees were transferred to other plants within the firm throughout the 1990s. This reflects the comprehensive nature of Japan's economic slowdown in the 1990s, in particular for Firm B in which nearly all of its product lines experienced sharp declines in demand. In addition, transfers

${ }^{19}$ For an earlier study of transfers of workers to other establishments within the firm, see Kato (1991). 


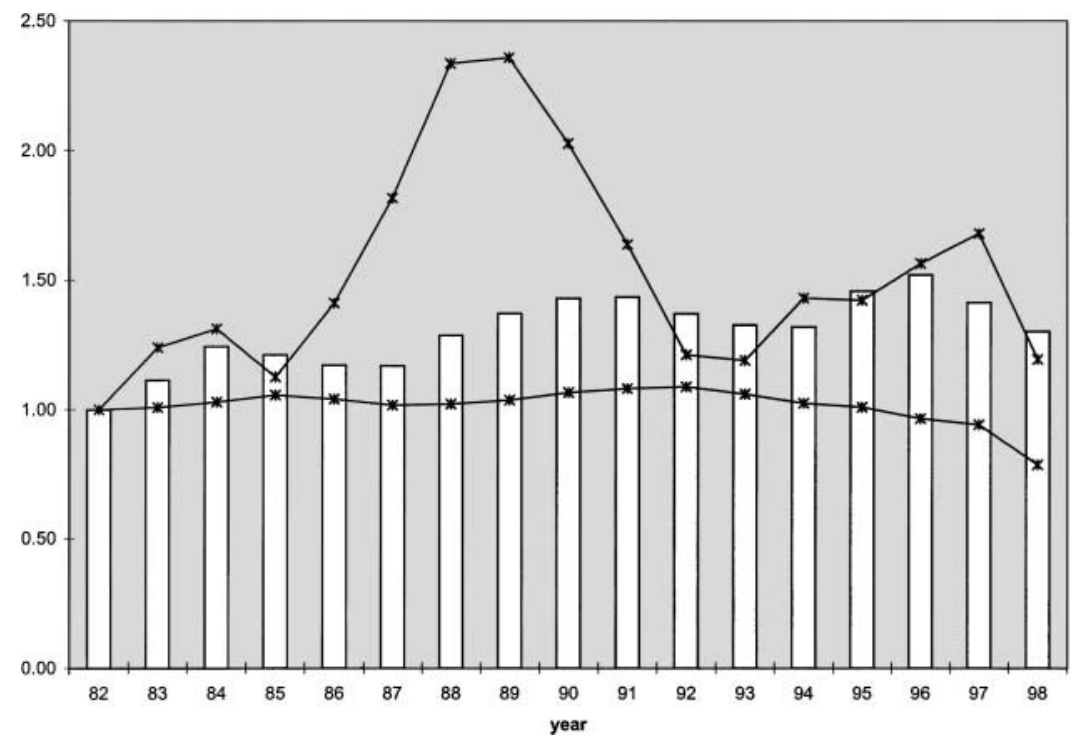

FIG. 5. Changes in key firm characteristics over time: Firm C. $\square$, sales; $*$, labor; $*$, share price.

to other plants within the firm often involves relocation of employees on transfer and their families, and increasingly more employees prefer transfers to other firms in the same vicinity (thus not requiring relocation) to transfers to other plants within the firm which necessitate relocation.

For production workers, the firm successfully induced early retirements in the 1990s. On average approximately 500 production workers nearing their retirement age of 60 have taken an early retirement option every year since 1991 . The firm has been offering a significant financial incentive for early retirements. For example, if a worker takes an early retirement option at age 50, he or she will receive over $\$ 150,000$ which amounts to roughly two years of earnings (base wage plus bonus) in addition to his or her normal pension. The amount of an incentive pay for early retirement decreases as one decides to reitre closer to his or her mandatory retirement age of 60 . For example, if a worker retires one year prior to the mandatory retirement age, he or she will get only about $\$ 30,000$ in addition to his or her normal pension.

\section{c. Firm C}

Firm $\mathrm{C}$ is a large manufacturer with sales of four trillion yen (about one fifth of which is export sales) and employment of over 65,000 workers in 1998. It is also listed in the first section of the Tokyo Stock Exchange.

Figures 5 and 6 summarize changes in key characteristics of Firm $C$ for the past two decades. As shown in Fig. 6, firm performance continued to worsen in the 1990s, and the firm's after-tax profit became negative in 1998 for the first time. It 


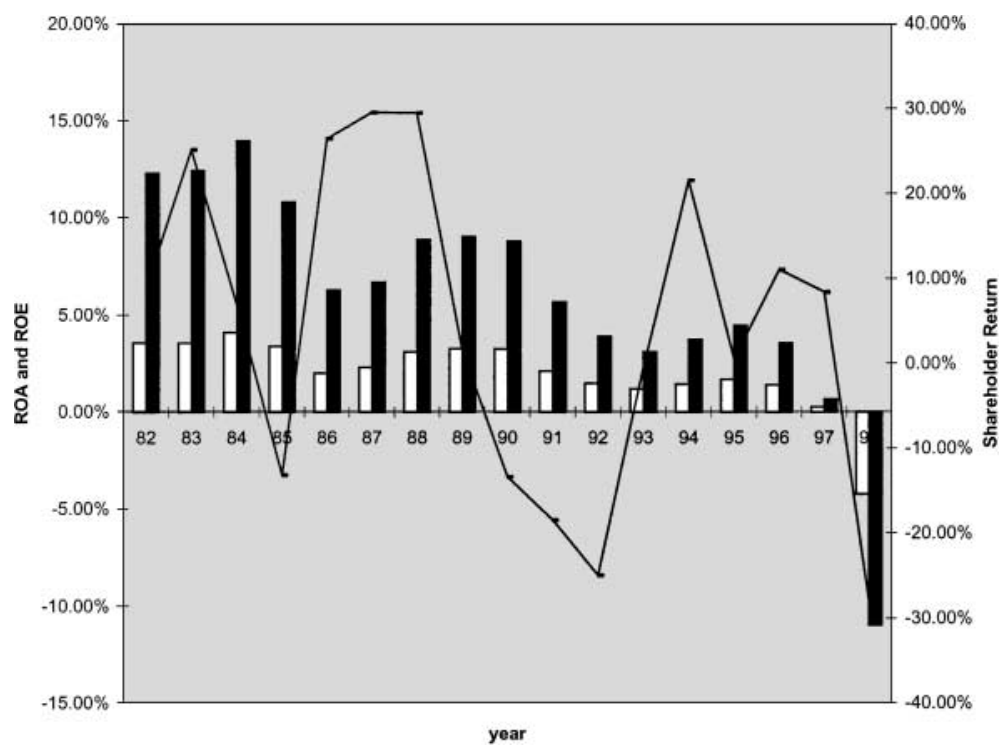

FIG. 6. Changes in firm performance measures over time: Firm C. $\square$, ROA; shareholder return.

slashed almost $25 \%$ of its labor force throughout the 1990s ${ }^{20}$ Like Firms A and B, this downsizing was primarily accomplished by a combination of limited hiring and transfers of workers to related firms without laying off workers.

As shown in Table VII, until the early 1990s, every year Firm C had hired around 4,000 college and high school graduates as regular employees right after their graduation. The firm reduced its hiring drastically (by three fourths) in the latter half of the 1990s, hiring only 800 to 1,100 per year. The hiring cut has been more acute for high school graduates than for college graduates. As such, the proportion of college graduates has doubled from about $35 \%$ in early 1990 s to $70 \%$ or more in the second half of the 1990s. In addition to hiring new graduates, the firm engaged in a small number of mid-career hires. Until only recently such hires were quite rare, constituting less than $3 \%$ of the total hires. However, the firm increased mid-career hires and now such hires constitute $8-11 \%$ of the total hires. Those mid-career hires were mostly young professionals, such as system engineers and financial analysts, in their 30s. The firm does not engage in any active raiding of employees from other firms yet does use a headhunting firm.

In addition to a hiring cut, like the above two cases, Firm C's primary mechanism of downsizing is transfers of its employees. Unlike Firm B, however, Firm C still uses transfers of employees to other establishments within the firm. Specifically,

${ }^{20}$ As shown in Fig. 5, unlike Firms A and B, Firm C has not experienced a serious decline in sales. Yet the firm has been downsizing its labor force in response to worsening profitability, measured by ROA, ROE, and shareholder returns. What has been causing Japanese firms to downsize their labor force is an important and interesting question. However, it is beyond the scope of this paper. 


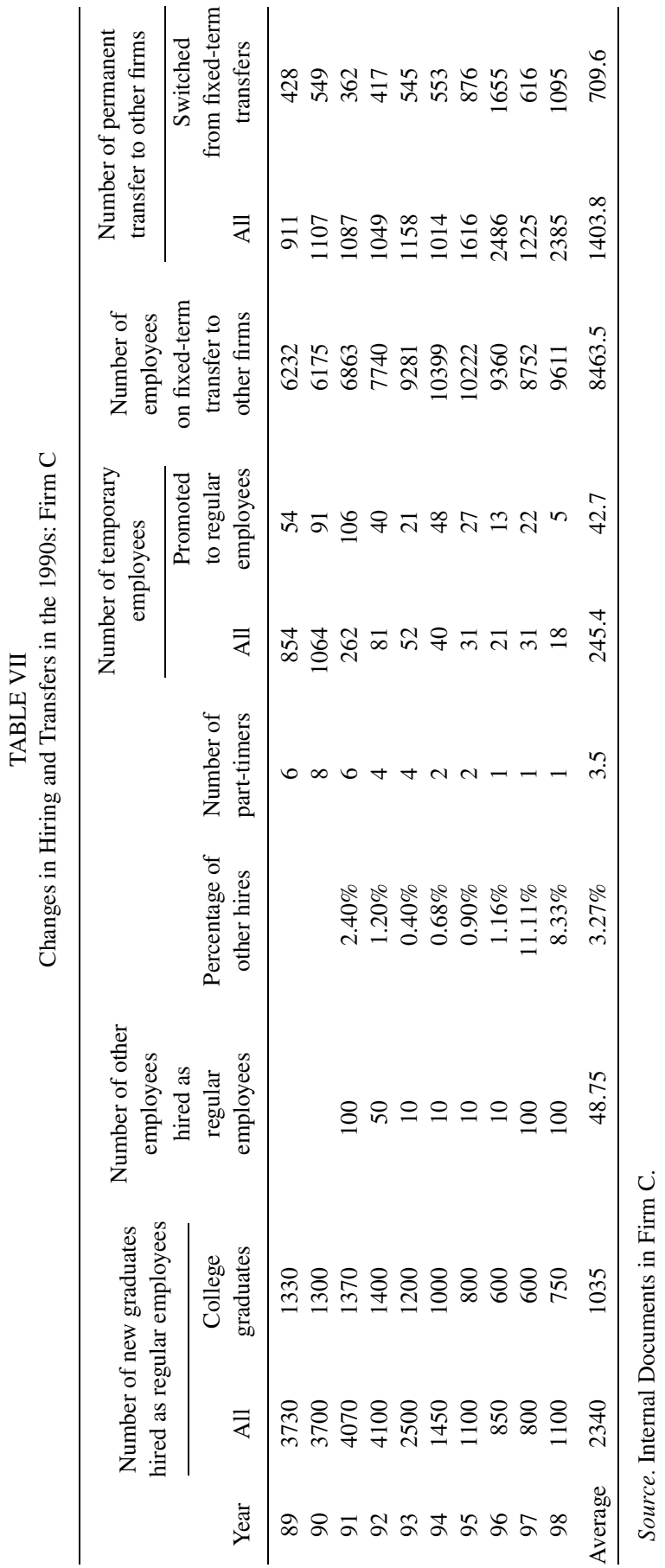


in 1991 through 1993, 290 production workers were permanently transferred from the home appliance division to the industrial appliance division. Both divisions require similar skills, yet work in the industrial appliance division tends to be more physically demanding. Since both divisions are in the same vicinity, these permanent transfers did not require any relocation of these employees. In 1992 to 1993, 190 white-collar employees (mostly engineers) were permanently transferred to the firm's sales department. Engineers who were designing various appliances ended up working in sales. This represents a substantial change in the nature of work and relocation. From 1993 to 1995, 750 employees, including both blue-collar and white-collar, were permanently transferred from the home appliance division to other divisions within the same vicinity. From 1994 to 1996, 210 employees (both blue-collar and white-collar) were transferred permanently from the home appliance division to the information technology (IT) division in the same city. Most recently, in 1998-99, 800 white-collar employees in a variety of functional departments (such as research and development, accounting, HR, sales, and marketing) in various divisions were permanently transferred to their counterparts in the IT division. All employees received 20 days of training on information technology.

Like Firms $\mathrm{A}$ and B, Firm $\mathrm{C}$ in its effort to downsize avoided layoffs by extensively using fixed-term and permanent transfers to other firms. As shown in Table VII during 1989-98, Firm $\mathrm{C}$ had an average of about 8,500 employees on fixed-term transfer each year. The number rose over the period and remained about at the 10,000 level in late 1990s. Throughout the period of $1989-98$ over $10 \%$ of Firm C's total labor force were on fixed-term transfers each year. Nearly $90 \%$ of those on fixed-term transfers were at Firm C's subsidiaries and other related firms. The rest of them were in a variety of places such as government agencies. The term of transfer is normally one to three years. Those on transfer for the purpose of helping subsidiaries and other related firms as advisors will normally return to Firm C after their terms. However, in the 1990s, increasingly more employees were transferred to subsidiaries and other related firms as a result of business restructuring and downsizing of Firm $\mathrm{C}$ (for example, transferring a business segment of Firm $\mathrm{C}$ to subsidiaries). Those employees tended to have their contracts of transfer extended and in the end be permanently transferred. Normally the official switch of employment from Firm $\mathrm{C}$ to their respective firms takes place when employees reach ages 50-55. Firm C's mandatory retirement age is 60, and many recent permanent transfers can be viewed as a kind of early retirement with post-retirement jobs arranged by the firm.

As shown in Table VII, on average, from 1989-1998 about 1,400 employees were permanently transferred per year, and the figure was rising over the period, surpassing the 2000 level in 1998. Nearly all of those permanent transfers were to subsidiaries and related firms. About half of those permanent transfers were switches from fixed-term transfers to permanent transfers. Since the average number of employees on fixed-term transfer from 1989-1998 was 8,500, each year 8\% of those on fixed-term transfer were switched to permanently transferred.

There is no formal mechanism of prior consultation with those considered for fixed-term transfers. On the other hand, for permanent transfers, there is an 
agreement between labor union and management which requires management to consult with those considered for such transfers. However, it has been often the case that permanent transfers are necessitated by transferring a certain business segment to a related firm. In such a case, there is really no place to go back within Firm $\mathrm{C}$ even if one prefers to return to Firm C. Employees often find it impossible to return to Firm $\mathrm{C}$ even if they wish to do so.

Sometimes wages of permanently transferred employees go down at their new firms. Firm $C$ will pay those employees a lump-sum severance pay to make up for the decline in their pay. As a result of recent surges in transfers, more and more new graduates at their interviews with Firm $\mathrm{C}$ tend to ask if the firm has any future plans to spin off some of its business segments. However, Firm C's HR managers feel that recent increases in permanent transfers have not had any significant adverse effects on employee morale.

In 1996, Firm C introduced an early retirement option combined with a paid leave of absence. The policy allows each employee over 45 taking an early retirement option to take a paid leave of absence up to one year prior to retirement. During this preparation period, each employee prepares for post-retirement life while being paid a full base wage. During the first year of the policy, 302 employees (120 of them were supervisors) took the early retirement option with a paid leave of absence. The number fell to 78 (12 supervisors) in 1997 but rose back to 237 (68 supervisors) in 1998. Sixty-four percent of early retirees were aged 55-59; $27 \%$ were 50-54; and $9 \%$ were 45-49. There were a variety of activities the early retirees participate in. Some went to English schools during their paid leave of absence and became English teachers. Some prepared for the licensing exam for radiological technologists. Many went back to their hometowns and became farmers. Some also started their own businesses such as a car dealership in their hometowns.

\section{d. Concluding Remarks from Field Research}

1. Avoidance of layoffs as a means of restructuring or downsizing: In spite of the sizable downsizing of the labor force that each of our firms carried out in the 1990s (ranging from 25 to 50\%), no firm used layoffs as a means to achieve such restructuring or downsizing. ${ }^{21}$

2. Extensive use of transfers to subsidiaries and related firms: Instead of laying off employees, each firm transferred a significant number of their senior employees to its subsidiaries and related firms first on a fixed-term basis. A large proportion of those on fixed-term transfer are eventually transferred permanently. ${ }^{22}$ These permanent transfers occur only for those in their 50s, in particular over 55. They can be viewed as early retirements with guaranteed jobs primarily at subsidiaries and related firms. Put differently, large firms in Japan have been

${ }^{21}$ According to Chuma (1998b), a change in the legal environment in Japan following the first oil crisis in the mid-1970s made it more difficult for Japanese employers to lay off their employees in recent years.

${ }^{22}$ For nonmanufacturing firms, Chuma (2001) reports a similar use of fixed-term and permanent transfers by a large firm in the domestic commerce sector in Japan. 
downsizing their labor force by expanding the definition of the firm to include the firm's subsidiaries and related firms. Lifetime employment with the firm now often means lifetime employment with the firm and its subsidiaries and related firms. ${ }^{23}$

3. Drastic hiring cut: Each firm reduced its hiring of new graduates drastically. ${ }^{24}$ This has two important consequences. First, it is creating a serious youth unemployment problem. For example, the unemployment rate in Japan has risen most rapidly for those aged 15-24 in the 1990s. ${ }^{25}$ Second, the firm's labor force is aging rapidly, which weakens the dynamism of the organization.

4. Significant early retirement incentive plans: Each firm used an early retirement incentive plan primarily to induce those employees nearing their mandatory retirement age to retire early. The amount of the incentive appears to be far from trivial, and each firm induced a substantial number of early retirements successfully.

5. The job retention rates calculated in the previous section may need to be interpreted with some caution. Specifically, our field research shows that firms have been carrying out their downsizing by relying heavily on the extensive use of fixedterm transfers of employees to their subsidiaries and related firms. In addition, as shown by our field research, many of those on fixed-term transfer never return to their original firms and are permanently transferred. One may argue that the length of time each employee spends while on fixed-term transfer prior to becoming permanently transferred should not be considered part of his or her tenure with the original firm since both the firm and the employee understand that his or her employment with the firm ends de facto when he or she is transferred on a fixedterm basis. In other words, the employee's eventual tenure with the original firm may be overstated in the Employment Status Survey. This argument is entirely plausible yet the magnitude of this bias may not be large enough to overturn our key findings from the job retention rates since typically the term of such transfers is one to three years. Unfortunately, we have no systematic evidence to precisely gauge the magnitude of this bias. ${ }^{26}$

${ }^{23}$ Japanese Ministry of Labor publishes two types of aggregate quantitative data on the importance of fixed-term transfers. First, the 1998 Survey on Employment Trends reports that fixed-term transfers accounted for $27 \%$ of all job losses (excluding job losses due to mandatory retirement and the conclusion of term-employment) in 1998. The figure rose to $31 \%$ in 2000 according to the most recent issue of the Survey. Second, recent issues of the Survey on Labor Economy Trends show that fixed-term transfers are one of the most commonly used employment adjustment methods (for example, during the third quarter of $2000,30 \%$ of firms which reported to have carried out downward employment adjustment used fixed-term transfers) and that they are far more common than layoffs and "voluntary" retirement (kibo taishoku) combined.

${ }^{24}$ A similar use of hiring cuts as an important device of downsizing in the spinning industry was documented in Higuchi (1997).

25 See, for instance, Genda (2000).

${ }^{26}$ Alternatively, if one believes that the notion of lifetime employment has changed to include the post-transfer employment at subsidiaries in the Japanese society, then the standard retention rate would understate the importance of the new notion of lifetime employment. 


\section{CONCLUSIONS}

In this paper we have shown that contrary to the popular rhetoric of the end of lifetime employment, evidence points to the enduring nature of this practice in Japan. Specifically, we have found little evidence for any major decline in the job retention rates of Japanese employees from the period prior to the burst of the bubble economy in the late 1980s to the post-bubble period. Generally, our field research has corroborated the main finding from the job retention rates by depicting vividly that large firms in Japan have been trying to accomplish their restructuring and downsizing targets by relying heavily on transfers of their employees to their subsidiaries and related firms and hiring cuts, and thus avoiding layoffs. Last, we have found some evidence that the burden of downsizing appears to fall disproportionately on young workers and middle age workers with shorter tenure.

These are still preliminary observations. Clearly more work is necessary to make more definitive answers to these important questions. In particular, additional work in the following two areas is needed. First, our field research at large firms reveals their extensive use of transfers (both fixed-term and permanent) of regular workers to their subsidiaries and related firms as a way to avoid laying off their regular workers. An obvious question is in what way those subsidiaries and related firms have been absorbing an increasing flow of labor force from their parent firms. A closer look at these outlets of transfers (or subsidiaries, related firms, and other firms to which employees have been transferred) is urgently needed.

Second, our qualitative data were obtained from extensive interviews with HR managers, line supervisors, and top union officials, and thus the perspectives of the rank and file were not fully accounted for. For example, both HR managers and top union officials tend to view the increasing incidents of permanent transfers in recent years as a necessary modification of the notion of lifetime employment rather than the end of lifetime employment. Do ordinary employees feel the same way? Especially, those permanently transferred employees may view the rising use of permanent transfers as reneging a no-layoff pledge on the side of the company. We cannot address these issues fully until we conduct extensive worker interviews or worker surveys. However, we did ask both HR managers and top union officials how ordinary employees react in general when they are asked to be transferred. Both HR managers and union officials acknowledged that these employees were generally unhappy about the prospect of becoming employees of somewhat less prestigious subsidiaries and related firms. Nonetheless, those employees are also fully aware, as both HR managers and union officials point out, that there would be no future career advancement for them in the parent firm and that they will likely be assigned to dead-end jobs even if they stay in the parent firm. ${ }^{27}$

${ }^{27}$ This finding from our field research at manufacturing firms may extend to nonmanufacturing firms since Chuma (2001) reports a similar finding from his field research at a large nonmanufacturing firm. 


\section{REFERENCES}

Abraham, K., and Houseman, S. (1989). Job security and work force adjustment: How different are U.S. and Japanese practices? J. Japan. Int. Econ. 3, 500-521.

Aoki, M. (1990). Toward an Economic Model of the Japanese Firm, J. Econ. Lit. 28, 1-27.

Brunello, G. (1988). Transfers of employees between Japanese manufacturing enterprises: Some results from an enquiry on a small sample of large firms. British J. Ind. Rel. 26, 119-132.

Chuma, H. (1998a). Is Japan's long-term employment system changing? in "Internal Labour Markets, Incentives and Employment" (I. Ohashi and T. Tachibanaki, Eds.), pp. 225-268, St. Martin's Press, New York.

Chuma, H. (1998b). Kaikoken Ranyohori no Keizai Bunseki: Koyo Keiyakuriron no Shitenkara (An Economic Analysis of the Legal Principle of Abuse of the Right to Dismissal), in "Kaishaho no Keizaigaku (the Economics of Corporate Law)" (Y. Miwa, H. Kanda, and N. Yanagawa, Eds.), University of Tokyo Press, Tokyo.

Chuma, H. (2001). Employment adjustments in Japanese firms during the current crisis, mimeo, Hitotsubashi University.

Clark, R. L., and Ogawa, N. (1992). Employment tenure and earnings profiles in Japan and the United States: Comment, Amer. Econ. Rev. 82, 336-345.

Dore, R. (1996). "The End of Jobs for Life? Corporate Employment Systems: Japan and Elsewhere," Centre for Economic Performance Occasional Paper 11, London School of Economics.

Farber, H. S. (1998). Are lifetime jobs disappearing? Job duration in the United States: 1973-1993, in "Labor Statistics Measurement Issues" (J. Haltiwanger, M. Manser, and R. Topel, Eds.), University of Chicago Press, Chicago.

Genda, Y. (2000). "Who Really Lost Jobs in Japan? Youth Employment in Aging Japanese Society," Paper presented at the joint JCER-NBER Conference on Labor Markets and Firm Benefit Policies in Japan and the United States, January 20-23, Hawaii.

Hall, R. E. (1982). The importance of lifetime jobs in the U.S. economy, Amer. Econ. Rev. 72, 716-724.

Hashimoto, M., and Raisian, J. (1985). Employment tenure and earnings profiles in Japan and the United States, Amer. Econ. Rev. 75, 721-735.

Hashimoto, M., and Raisian, J. (1992). Employment tenure and earnings profiles in Japan and the United States: Reply, Amer. Econ. Rev. 82, 346-354.

Higuchi, Y. (1997). Trends in Japanese labour markets, in "Japanese Labour and Management in Transition: Diversity, Flexibility and Participation” (M. Sako and H. Sato, Eds.), pp. 27-52, Routledge, London.

Hoshi, T., and Kashyap, A. (1999). "The Japanese Banking Crisis: Where Did It Come From and Where Did It End,” NBER Working Paper 7250, July. Japan Statistics Bureau, Ministry of Public Management, Home Affairs, Posts, and Telecommunications (various years). Shugyo Kozo Kihon Chosa [Employment Status Survey].

Jones, D., and Kato, T. (1995). The productivity effects of employee stock ownership plans and bonuses: Evidence from Japanese panel data. Amer. Econ. Rev. 85, 391-414.

Kato, T. (1991). Specific human capital and worker transfers as an alternative to layoffs: Theory and evidence, Ricerche Econ. 45, 397-420.

Kato, T. (2000). “The Recent Transformation of Participatory Employment Practices in Japan,” NBER Working Paper 7965, October.

Kato, T., and Morishima, M. (2001). The productivity effects of participatory employment practices: Evidence from new Japanese panel data, Industrial Relations, in press.

Koike, K. (1991). "Economics of Work," Toyo Keizai, Tokyo. [In Japanese]

Levine, D. I. (1995). “Reinventing the Workplace,” Brookings Institution, Washington, D.C. 
Morishima, M. (1992). Japanese employees' attitudes toward changes in traditional employment practices, Ind. Relations 31, 433-454.

Nakata, Y. (2000). "Total Labor Cost and Employment Level Adjustment Under Shukko System," Paper presented at the joint JCER-NBER Conference on Labor Markets and Firm Benefit Policies in Japan and the United States, January 20-23, Hawaii.

Neumark, D., and Polsky, D. (1998). Changes in job stability and job security, in "Proceedings of the 50th Annual Meeting” IRRA Series, Vol. 1, pp. 78-87.

Patrick, H. (1998). “The Causes of Japan's Financial Crisis,” Working Paper 146, Center on Japanese Economy and Business, Columbia University, August.

Suruga, T. (1998). Employment adjustment in Japanese firms: Negative profits and dismissals, in "Internal Labour Markets, Incentives and Employment” (I. Ohashi and T. Tachibanaki, Eds.), pp. 196-221, St. Martin's Press., New York. 